資 料

\title{
大学生の独自性欲求の類型化に関する研究
}

\author{
宮 下 一 博*
}

\section{A STUDY ON NEED FOR UNIQUENESS IN ADOLESCENTS}

\author{
Kazuhiro Miyashita
}

\begin{abstract}
The purposes of the present study were to explore the possibility of typing 'need for uniqueness' proposed by Snyder and Fromkin, and to examine the characteristics of these types. New items measuring need for uniqueness, the Japanese version of the need for uniqueness scale developed by Snyder and Fromkin, and the mental set scale for creativity by Mishima et al. were administered to 224 university students. By means of various statistical analyses, a new reliable and valid scale for measuring need for uniqueness (Uniqueness Scale) was constructed. In accordance with this scale, 'need for uniqueness' was divided into four types : (a) going my way (calm) type ; (b) repressed type ; (c) self-exhibited type, and (d) self-centered type. Among these types, going my way and self-exhibited types were seen showing higher scores in mental set scale for creativity.
\end{abstract}

Key words : need for uniqueness, Uniqueness Scale.

\section{問題と目的}

Snyder \& Fromkin（1980）によって提唱された「独 自性理論」(Theory of Uniqueness) では，人間の基本的 な欲求として,「他者とは異なるユニークな存在であり たい」という独自性欲求 (need for uniqueness)をその中 核に据えている。これに関する研究の概要は, 岡本 $(1982,1985)$ に譲るが, 人間存在の根本に関わる興味深 い理論である。我国では, Okamoto(1983)，岡本(1985) がこれに関する先駆的な研究を行っている。まず, Okamoto（1983）は, Fromkin $(1970,1972)$ 基づい て,この理論に関する基礎的研究を行い, 性格や態度, 興味に関して「他の人と非常に類似している」という 内容のフィードバックを受けた人は, 「類似度が中程 度」という内容のフィードバックを受けた人に比べて, より否定的な情動を体験していることなどを報告して いる。また, 岡本 (1985) は, Snyder \& Fromkin が作

* 千葉大学 (Chiba University)
成した独自性欲求を測定する尺度を我国に導入し，そ の信頼性や妥当性について検討している。この尺度は, 上記のようなフィードバック・パラダイムとともに, その個人差をとらえる主要な測定具と考えられ, 信頼 性と妥当性を我国において，吟味することが目的とさ れた。そして，この尺度が測定しているものは，1つ の概念としてまとまりを持つ安定した個人差に関わる 変数であること, 高い信頼性と妥当性が得られたこと などが報告されている。

しかし, 岡本 (1985) の独自性欲求尺度の因子分析の 結果や，大学生64名を対象とした筆者らの予備調査の 結果（「独自的な人とはどのような人だと思いますか?」との問 に対して箇条書的に回答) などから考えて, 質的に違いの ある独自性欲求の夕イプが存在することも考えられる。 予備調査の回答例を列挙すると, (1)自分なりの意見を 持っている人，(2)自分の個性を把握している人，(3)物 事を色々な側面から見ることができる人，(4)他人を気 にしない人，(5)まわりの人に流されない人，(6)人を笑 わせる人，(7)型破りなことをする人，8自分の思う通 
りに動く人，9自分のやりたいことができる人などと なり，これらの回答から「独自的な人」をとらえる視 点を探索した。そして，第1に，(4)や(5)，(8)，(9)のよ うに他人の存在をそれほど意識しないか，それとも(6) のように他人の存在にとらわれやすいかという視点, 第 2 に，(1)や(2)，(3)ように行動というよりもその人 の意識や認識のレベルを強調するか，それとも，(7)や (8)，(9)のうう積極的な行動を強調するかという視点， の 2 つが導き出された。本研究では, この予備調査の 結果を参考にして, 独自性欲求というものを, I「他 者の存在を気にするか否か」, II「自己を積極的に表出 するか否か」という 2 つの視点 (次元) からとらえ, 仮 説的に FIG. 1 に示す 4 類型を設定した。

他者の存在を気にしない。

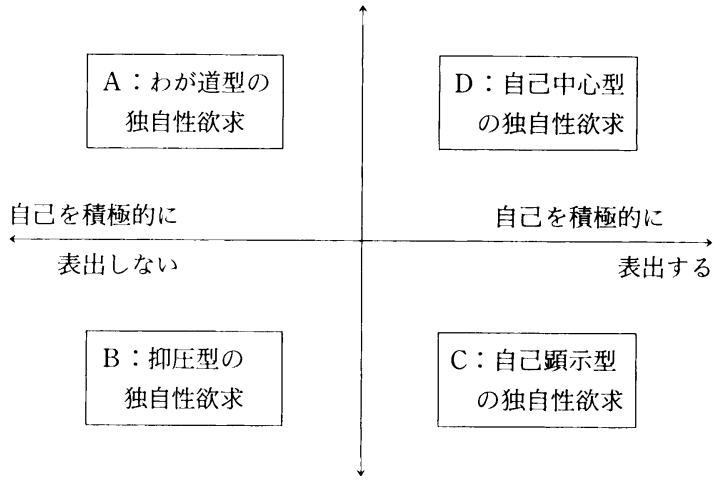

他者の存在を気にする

FIG. 1 独自性欲求の類型

本稿では, 上記のような独自性欲求の類型化が可能 であるか否か検討するとともに，それぞれの類型の特 徵を探索的に検討することを目的とした。

\section{方法}

調查対象 国立C大学学生 224名

調查時期 1987 年10月上旬

調查方法 以下の 3 種の質問紙を授業時間を利用し て集団的に実施した。

質問紙 (1)独自性欲求を測定する質問紙：上記 $2 つ$ の次元それぞれを測定すると考えられる項目を増田 (1988) が作成した。筆者ともう 1 名の研究者がその内 容的妥当性を吟味し，意見の一致をみた TABLE 1 に示 す18項目を選択した。回答は7 段階評定によりなされ， 各項目とも，他者の存在を気にしないほど，あるいは
自己を積極的に表出するほど高得点となるよう $7 〜 1$ 点を付与した。

TABLE 1 新しい独自性欲求を測定する項目の 項目一全体得点間相関係数

\begin{tabular}{|c|c|c|}
\hline (1) & 引込みじあんである。++せ21 & $.495^{* *}$ \\
\hline (2) & 自分に対する他人の評価が気になる。+ & $.655^{* *}$ \\
\hline 3 & $\begin{array}{l}\text { 型にはまったことをするよりかわったことをし } \\
\text { たい。++ }\end{array}$ & $.377^{* *}$ \\
\hline (4) & ついつい自分と他人を比較してしまう。+ & $.598^{* *}$ \\
\hline (5) & 誰からも嫌われたくない。+ & $.552^{* *}$ \\
\hline (6) & 我を通すことはあまり好まない。++ & $.374^{* *}$ \\
\hline (7) & 他人が自分に反対するといやな気持ちになる。+ & $.445^{* *}$ \\
\hline 8 & 人の話をきくより自分で話していたい方だ。++ & $.177^{* *}$ \\
\hline 9 & 世間体はそれほど気にしない。+ & $.556^{* *}$ \\
\hline 10 & いつでも積極的に自分の意見を述べる。++ & $.478^{* *}$ \\
\hline 11 & 他人の衍動にはあまり関心がない。+ & $.361^{* *}$ \\
\hline (12) & 人に見られているとついかっこうつけてしまう。+ & $.345^{* *}$ \\
\hline (13) & 恥ずかしがりやである。++ & $.400^{* *}$ \\
\hline 14 & $\begin{array}{l}\text { 人から「生意気だ」とか「うぬほれている」と } \\
\text { か言われたことがある。+ }\end{array}$ & $.231^{* *}$ \\
\hline (15) & 自分の容姿を気にする方である。+ & $.323^{* *}$ \\
\hline 16 & 自分の長所をできるだけアピールしていきたい。++ & .015 \\
\hline 17 & 私は○○さんよりは優れていると思っている。+ ${ }^{+}$ & $.159^{* *}$ \\
\hline (18) & 他の人に自分のことを認めてもらいたい。+ & $.343^{* *}$ \\
\hline & $\begin{array}{l}\text { 1） 印は逆転項目を示す。 } \quad{ }^{* *} \mathrm{p}<.01 \\
\text { 2) } \quad+\text { ：他者の存在を気にするか否かの次元を涀 } \\
++ \text { ：自己を積極的に表出するか否かの次元を }\end{array}$ & \\
\hline
\end{tabular}

(2)独自性欲求尺度：併存的妥当性を検討するため, 岡本（1985）が翻訳・作成した独自性欲求尺度32項目を そのまま使用した。 7 段階評定とし, 各項目とも得点 が高いほど独自性欲求が高くなるよう 7 ～1点を付与 し，総得点を算出した。

(3)創造的構えテスト：独自性欲求との関連を検討す るために使用された。三島・久米・青柳・星野・吉光 （1985）により作成され，6下位尺度68項目からなる。 下位尺度は，(1)自己信頼感，(2)持久力，(3)挑戦性，(4) 探求心，(5)細心さ，(6)客観性の 6 つである。回答は 7 段階評定とし, 各項目とも創造的構えの程度が高いほ ど高得点となるよう $7 \sim 1$ 点を付与し，各下位尺度得 点ならびに総得点を算出した。

\section{結果と考察}

1.新しい独自性欲求尺度（ユニークさ尺度）の作成

(1)項目分析 作成した18項目について, 各項目得点 と総得点との相関係数算出により項目分析を行い，そ の結果を TABLE 1 に示した。この結果に基づき, 有意 に達しない項目 $N_{0.16}$. 除外，残りの17項目を採択した。 
(2)因子分析 項目分析を通過した17項目について, 主因子解による因子分析を行った。それによれば，各 因子の固有值は，第 I 因子 3.45 , 第 II因子 2.65 , 第III 因子 1.30 ，第IV因子 1.17 , 第 V因子 1.09 などとなり， 第 I 因子，第II因子と第III因子以下とは明らかに差が 認められた。そこで，2因子構造を採用し，これに Varimax 回転を施し, TABLE 2 に結果の概要を示し た。ここで, 絶対値.35以上の因子負荷に着目し, 単純 構造をなす項目を選択すると (No.17 の項目は第 I 因子, 第 II 因子の負荷量の差が小さく除外)，第 I 因子（F I ）は，№.2， $4 ， 5 ， 7 ， 9 ， 11 ， 12 ， 15 ， 18 の 9$ 項目が，また，第 II 因子 (F II) は，№.1，3，6，8，10，13，14の 7 項目が それぞれ選出された。第 I 因子は,「他者評価からの自 由」の因子, 第II因子は,「積極的自己表出」の因子と 各々命名された**。第 I 因子が, 「他者の存在を気にす るか否か」, 第II因子が,「自己を積極的に表出するか 否か」に対応する次元であり，これらは独立した $2 つ$ の次元であることが確認された。以下，単純構造をな す項目 (TABLE 2 にイタリックで表示) の総和により，それ ぞれ因子得点を算出した。この尺度を「ユニークさ尺 度」と呼ぶ。

TABLE 2 因子分析の結果

\begin{tabular}{c|c|c|c}
\hline \multirow{2}{*}{ No. } & 因 子 & 負 & 荷 量 \\
\cline { 2 - 3 } & F I & F II & \multirow{2}{*}{$\mathrm{h}^{2}$} \\
\hline 1 & -.125 & -.681 & .480 \\
2 & -.715 & -.258 & .578 \\
3 & .147 & .447 & .221 \\
4 & -.739 & -.079 & .552 \\
5 & -.655 & -.029 & .430 \\
6 & -.055 & -.547 & .302 \\
7 & -.495 & -.110 & .257 \\
8 & -.201 & .413 & .211 \\
9 & .632 & .172 & .429 \\
10 & .098 & .754 & .579 \\
11 & .408 & .051 & .169 \\
12 & -.517 & .245 & .328 \\
13 & -.130 & -.510 & .278 \\
14 & -.087 & .378 & .150 \\
15 & -.515 & .104 & .276 \\
17 & -.298 & .391 & .242 \\
18 & -.595 & .296 & .442 \\
\hline 寄与率 & $19.92(\%)$ & $14.92(\%)$ & $34.84(\%)$ \\
\hline
\end{tabular}

** 2 因子の寄与率の合計が若干低いのは, 因子数の制限による ところが大きい。3因子構造以上を採択すれば，寄与率は大幅 に上がるが, 固有值との兼ね合いで 3 因子以上の因子を採択す ることは不可能であった。
(3)信頼性 ユニークさ尺度の16項目について，スピ アマン・ブラウンの公式による信頼性係数 (前後折半) を算出したところ, .720の值が得られ，この尺度の内的 整合性に基づく信頼性は低くないといえよう。

(4)妥当性 ユニークさ尺度の 2 つの因子 (次元) なら びに総得点と岡本 (1985) の独自性欲求尺度との相関係 数を算出し, TABLE 3 に結果を示した。その結果，い ずれも正の有意な相関が得られ，本尺度の併存的妥当 性の低くないことが検証された。

TABLE 3 ユニークさ尺度の妥当性の検討

\begin{tabular}{cc|c}
\hline ユニークさ尺度 & 独自性欲求尺度 & 相関係数 $(\mathrm{r})$ \\
\hline F I (他者の存在を気にするか否かの次元) & $.635^{* *}$ \\
F II (自己を積極的に表出するか否かの次元) & $.339^{* *}$ \\
\hline 合 & 計 & $.641^{* *}$ \\
\hline
\end{tabular}

** $\mathrm{p}<.01$

以上, 新しい独自性欲求尺度 (ユニークさ尺度) の作成 を行い, 独自性欲求を 4 つの型に分類する可能性が示 唆された。

ところで，人間存在の本質と結びついたこの独自性 欲求を充足することで，人はより生き生きとした精神 的活動を行うことができるであろう。そのことは，活 発な創造への意欲も生み出すことであろう。従って, 独自性欲求のタイプと創造性 (本研究でとりあげるのは, 創 造性の人格的基礎をなすと考元られる「創造的構え」）には，密 接な関係が見られることが予想される。そこで，次に， 「創造的構えテスト」との関連において，これら 4 つの 類型の特徵を若干明らかにしていくこととしたい。 FIG. 1 には各類型の暫定的な名称も付されている。こ れら 4 つの類型の価值づけは難しい点もあるが, これ らのうちでは, A 型すなわち,「わが道型の独自性欲求」 のタイプが対人関係にそれほど惑わされずに，もの静 かに自分の目標を着実に実現させていくという印象で, 独自性欲求の表出の仕方（あり方）としては，最も成熟 した類型のように思われる。一方，他の類型は，「まだ 自分自身や他者にとらわれている」面があり，A型よ りも「創造的構え」において低い得点を示すことが予 想される。

2.独自性欲求と創造的構えとの関連

ユニークさ尺度の 2 つの因子得点の平均（それぞれ 27.23, 28.90) をもとに, FIG. 1 に示す $\mathrm{A} \sim \mathrm{D}$ の 4 類型に 分類し, この 4 群の「創造的構え」の 6 下位尺度なら 
びに総得点の差違を一要因の分散分析により検討した。 その概要をまとめたものが，TABLE 4 である。それに 上れば，「自己信頼感」( $F=24.62, \mathrm{p}<.01)$, 「持久力」 $(\mathrm{F}=$ $3.14, p<.05)$, 「探求心」( $F=7.31, p<.01)$ の 3 つの下位尺度 及び「総得点」( $\mathrm{F}=4.72, \mathrm{p}<.01)$ において 4 群間に有意差 が認められた。また，これら有意差の得られたものに ついて, Ryan 法による多重比較を行い, 結果を TABLE 5 にまとめて示した。TABLE 5 より,「自己信頼感」の 得点は, $\mathrm{A}$ 型が $\mathrm{B}, \mathrm{D}$ 型よりも, また, $\mathrm{C}$ 型が $\mathrm{B}, \mathrm{D}$ 型よりも有意に高かった。「持久力」においては, 分散 分析では有意差は見られたものの, 多重比較の結果, いずれの 2 群間にも有意差は認められなかった。「探求 心」の下位尺度では，A，C型が $\mathrm{D}$ 型より有意に得点 は高かった。また，「創造的構え」の総得点において は,「自己信頼感」の下位尺度と同様, $\mathrm{A}, \mathrm{C}$ 型が $\mathrm{B}$, $\mathrm{D}$ 型よりもそれぞれ有意に高い得点を示した。

TABLE 44 類型の創造的構え得点の平均と分散分析 の結果

\begin{tabular}{|c|c|c|c|c|c|}
\hline 創造的構元 & $\mathrm{A}(\mathrm{N}=64)$ & $\mathrm{B}(\mathrm{N}=63)$ & $\mathrm{C}(\mathrm{N}=44)$ & $\mathrm{D}(\mathrm{N}=53)$ & F 值 \\
\hline 自己信頼感 & $\begin{array}{l}65.31 \\
(7.59)^{n *}\end{array}$ & $\begin{array}{l}56.81 \\
(8.02)\end{array}$ & $\begin{array}{l}66.27 \\
(8.70)\end{array}$ & $\begin{array}{l}56.87 \\
(6.65)\end{array}$ & $24.62^{* *}$ \\
\hline 持久力 & $\begin{array}{l}54.72 \\
(9.55)\end{array}$ & $\begin{array}{l}52.89 \\
(8.91)\end{array}$ & $\begin{array}{c}51.27 \\
(10.15)\end{array}$ & $\begin{array}{l}56.53 \\
(7.69)\end{array}$ & $3.14^{*}$ \\
\hline 挑戦 性 & $\begin{array}{l}45.77 \\
(7.21)\end{array}$ & $\begin{array}{l}43.24 \\
(6.87)\end{array}$ & $\begin{array}{l}45.75 \\
(7.51)\end{array}$ & $\begin{array}{l}43.77 \\
(7.39)\end{array}$ & 1.19 \\
\hline 探求心 & $\begin{array}{l}53.75 \\
(6.94) \\
\end{array}$ & $\begin{array}{l}51.75 \\
(6.55) \\
\end{array}$ & $\begin{array}{l}54.98 \\
(6.99) \\
\end{array}$ & $\begin{array}{l}49.06 \\
(6.94) \\
\end{array}$ & 7.31** \\
\hline 細 心 さ & $\begin{array}{l}40.53 \\
(5.34) \\
\end{array}$ & $\begin{array}{l}41.62 \\
(4.48)\end{array}$ & $\begin{array}{l}41.14 \\
(5.45) \\
\end{array}$ & $\begin{array}{l}42.17 \\
(4.01)\end{array}$ & 1.21 \\
\hline 観 性 & $\begin{array}{l}46.66 \\
(6.07) \\
\end{array}$ & $\begin{array}{l}44.67 \\
(6.37)\end{array}$ & $\begin{array}{l}46.77 \\
(6.50)\end{array}$ & $\begin{array}{l}46.11 \\
(5.79)\end{array}$ & 1.45 \\
\hline 計 & $\begin{array}{l}306.73 \\
(27.51)\end{array}$ & $\begin{array}{l}290.97 \\
(27.32)\end{array}$ & $\begin{array}{l}306.18 \\
(32.85)\end{array}$ & $\begin{array}{l}294.51 \\
(25.56)\end{array}$ & $4.72^{* *}$ \\
\hline
\end{tabular}

注）下段の数值はSD $\quad * * \mathrm{p}<.01 \quad * \mathrm{p}<.05$

TABLE 5 多重比較の結果（左の型一右の型の $\mathrm{t}$ 值）

\begin{tabular}{r||c|r|r|r|r|r}
\hline 類型 & $\mathrm{A}-\mathrm{B}$ & $\mathrm{A}-\mathrm{C}$ & $\mathrm{A}-\mathrm{D}$ & $\mathrm{B}-\mathrm{C}$ & $\mathrm{B}-\mathrm{D}$ & $\mathrm{C}-\mathrm{D}$ \\
\hline 創造的構え & & & & & & \\
\hline \hline 自己信頼感 & $6.19^{*}$ & -0.63 & $5.87^{*}$ & $-6.22^{*}$ & -0.04 & $5.96^{*}$ \\
\hline 持 久 力 & 1.13 & 1.94 & -1.07 & 0.92 & -2.15 & -2.84 \\
\hline 探 求 心 & 1.67 & -0.92 & $3.69^{*}$ & -2.40 & 2.11 & $4.24^{*}$ \\
\hline 合 計 & $8.33^{*}$ & 0.26 & $6.17^{*}$ & $-7.26^{*}$ & -1.78 & $5.37^{*}$ \\
\hline
\end{tabular}

* $\mathrm{p}<.05$
上記の結果をまとめると, 創造的構えの得点におい ては，全般的に $\mathrm{A}$ 型や $\mathrm{C}$ 型が $\mathrm{B} ， \mathrm{D}$ 型よりも有意に高 いといえそうである。A型が $\mathrm{B}$ ，D型に比べ得点が高 いという結果は予想を支持するものであった。A型と C型の間に差が見られなかった原因としては，C型の 特徵を再吟味することによって理解できる面もあろう。 つまり，C型は, FIG.1にあるように, 自己表出を盛ん に行うが，それはあくまでも，「他者の存在を念頭に置 いた上で」行われるのである。他者の存在に気を配り ながら，それに応じて自己表出を行うわけである。こ れは, 独自性欲求表出の観点からは, かなり健全な夕 イプといってよいかもしれない。それ故,「創造的構え」 の「自己信頼感」などの下位尺度や「全体得点」にお いて, A型と同程度の得点を示したのではなかろうか。 当初は, C型のこの特徵を軽視していたために, この ような結果は予想できなかったが，こうして見てくる と，C型が「人を気にしつつ自己表出をしない」B型 や，「人を見ずに一方的に自己表出をする」D型に比 べより高い「創造的構え」得点を示したことはかな り理解できるように思われる。また，予想した通り， $\mathrm{B}$ 型と $\mathrm{D}$ 型の間には「創造的構え」得点に差は認めら れなかった。B型は周囲の人のことが気になる余り自 己の表出が抑制されているタイプ，D型は他者とは無 関係に一方的に自己表出を目指そうとするタイプであ り，いずれも独自性欲求表出の仕方としては未熟な夕 イプといえよう。B型やD型から脱し， A 型やC 型に 移行することが, 独自性欲求表出の仕方としてはより 成熟したものであり，そのようなタイプに移行するこ とによって, 自己の内面を十全に表現できるだけの健 全な創造的活動が可能になるということであろう。

なお, 本研究では, FIG. 1 の 4 類型の分類は, サンプ ルの平均值に基づいて行った。今後, より被験者を増 やすことにより，(1)標準偏差を加味した分析を行うこ と，(2)各類型のより明確な判定基準を作成することな どが課題となろう。

\section{引用文献}

Fromkin, H.L. 1970 Effects of experimentally aroused feelings of undistinctiveness upon valuation of scarce and novel experiences. Journal of Personality and Social Psychology, 16, 521 -529 .

Fromkin, H.L. 1972 Feelings of interpersonal undistinctiveness : An unpleasant affective state. Journal of Experimental Research in 
Personality, 6, 178-182.

増田浩子 1988 現代青年の独自性欲求に関する一研 究 千葉大学卒業論文 (未公刊)

三島正英・久米稔・青柳肇・星野美智子・吉光清 1985 創造的構え (MSC) の安定性について一中 1 時 と中 2 時の比較一 日本教育心理学会第27回総会 発表論文集, 782-783.

岡本浩一 1982 “独自性理論”における類似性に関 して 心理学評論, 25, 165-177.

Okamoto, K. 1983 Effects of excessive similarity feedback on subsequent mood, pursuit of difference, and preference for novelty or scar- city. Japanese Psychological Research, 25, 69 -77 .

岡本浩一 1985 独自性欲求の個人差測定に関する基 礎的研究 心理学研究, 56, 160-166.

Snyder, C.R., \& Fromkin, H.L. 1980 Uniqueness :

The human pursuit of difference. New York: Plenum Press.

付 記

本稿は，筆者の指導に基づく増田（1988）の資料を再 構成して, 筆者の責任のもとに発表するものである。

(1990年 8 月11日受稿) 